\title{
Jarosław Olejniczak
}

Uniwersytet Ekonomiczny we Wrocławiu

e-mail: jaroslaw.olejniczak@ue.wroc.pl

\section{PROBLEM WYDAJNOŚCI \\ PRZEJMOWANYCH WPEYWÓW Z WYBRANYCH PODATKÓW W GMINACH WIEJSKICH}

\section{THE PROBLEM OF EFFICIENCY \\ OF ACQUIRED INCOMES FROM SELECTED TAXES IN RURAL COMMUNITIES}

DOI: $10.15611 / \mathrm{pn} .2017 .485 .26$

JEL Classification: H71, H77

\begin{abstract}
Streszczenie: Celem niniejszego artykułu jest weryfikacja hipotezy o malejącym znaczeniu dochodów podatkowych z podatków, w przypadku których gminy nie mają władztwa podatkowego, lecz jedynie czerpią środki finansowe dla budżetów gmin wiejskich. W celu weryfikacji hipotezy przeprowadzona została analiza statystyczna danych o wielkości wpływów ze wspomnianych podatków pochodzących ze sprawozdań z wykonania budżetów gmin w latach 2013-2015. Podjęte badania wskazały, iż od 2010 roku, mimo wzrastającego udziału dochodów własnych w dochodach ogółem, w przypadku zarówno ogółu gmin, jak i gmin wiejskich obserwowalny jest spadek uzyskiwanych przez wszystkie gminy dochodów nominalnych z analizowanych podatków, co skutkuje spadkiem ich udziałów w dochodach ogółem. Podsumowując, należy wskazać, iż badane źródła dochodów mają w większości gmin wiejskich marginalne znaczenie ze względu na słabą bazę podatkową w większości badanych gmin wiejskich.
\end{abstract}

Słowa kluczowe: transfery fiskalne, gminy, podatki.

Summary: The purpose of this paper is to review the hypothesis of the diminishing importance of tax revenue from taxes for which municipalities have no tax authority and only derive financial resources (tax card), civil law tax (PCC), inheritance tax (SPD) for budgets of rural communities. For the verification of the hypothesis, a statistical analysis of the data on the magnitude of the revenues from the above-mentioned taxes from the municipal budgets reports in the years 2013-2015 was carried out, followed by an analysis of the results obtained for 2015. At the same time, the assessment of the importance of these taxes to gminas in the spatial arrangement was carried out. The analysis was also aimed at answering the question of the appropriateness of the post-years needed to differentiate the municipal income system taking into account the municipality type (rural, urban and urban-rural), as well as assessing the occurrence and extent of spatial differentiation of the efficiency of these taxes. The researches indicated that since 2010, despite the growing share of own incomes in total incomes, both in 


\begin{abstract}
the case of the communes and in the case of rural gminas, there is a decrease in the nominal incomes of the analyzed taxpayers, which results in a decrease of their share in total income. In the case of rural municipalities, there was a similar tendency outside of PCC, where rural communes recorded an annual increase in the nominal value of their income. The differentiation of rural municipalities in individual taxes shows that, compared to the other municipalities, the difference in the share of income from the above-mentioned personal income and the per capita income per capita is slightly different - with few significant deviations from the median value (especially for PCC). The analyzed territorial distribution of both the share of income and the per capita income survey yields the conclusion that the concentration of higher values of the indicators obtained is visible mainly around strong urban centers and in voivodships considered economically strong (Mazowieckie, Śląskie, Wielkopolskie, Dolnośląskie and Pomorskie). In summary, it should be pointed out that the studied sources of income play marginal importance in most the rural gminas due to the weak tax base in most of the examined rural communes.
\end{abstract}

Keywords: fiscal transfers, municipalities, taxes.

\title{
1. Wstęp
}

Transfery fiskalne z budżetu państwa do budżetów jednostek samorządu terytorialnego kojarzone są zazwyczaj z dwoma ich rodzajami - strumieniami dotacyjno-subwencyjnymi oraz z udziałami w podatkach stanowiących dochody budżetu państwa (PIT oraz CIT). Dopiero po głębszym zastanowieniu przychodzi refleksja, iż w przypadku gmin za transfery tego rodzaju można uznać podatki, w przypadku których gminy nie mają władztwa podatkowego, lecz jedynie czerpią środki finansowe przypisane im ustawą o dochodach jednostek samorządu terytorialnego jako dochody własne, a zależne - ogólnie ujmując - od ich właściwości miejscowej. W literaturze przedmiotu (por. np. [Kosek-Wojnar, Surówka 2002]) wyodrębniane są one jako osobna grupa dochodów własnych. Do podatków o takim charakterze zaliczyć można podatek dochodowy opłacany w formie karty podatkowej, podatek od spadków i darowizn oraz podatek od czynności cywilnoprawnych.

Celem niniejszego artykułu jest weryfikacja hipotezy o mniejszym znaczeniu oraz mniejszej wydajności per capita tychże dochodów podatkowych dla budżetów gmin wiejskich na tle innych typów gmin. Aby zweryfikować hipotezę, przeprowadzono analizę statystyczną danych o wielkości wpływów ze wspomnianych podatków pochodzących ze sprawozdań z wykonania budżetów gmin w latach 20132015. Jednocześnie przeprowadzono ocenę zróżnicowania znaczenia i wydajności per capita tychże podatków dla gmin w układzie przestrzennym. Przeprowadzona analiza powinna także odpowiedzieć na pytanie o zasadność stawianych postulatów konieczności różnicowania systemu dochodów gmin uwzględniającej typ gminy (wiejski, miejski i miejsko-wiejski), jak również zweryfikować ocenę występowania i skali przestrzennego zróżnicowania wydajności tych podatków. 


\section{System i struktura dochodów gmin w Polsce}

Przyjęte rozwiązania $\mathrm{w}$ zakresie finansowania jednostek samorządu terytorialnego w Polsce charakteryzują się zróżnicowaniem źródeł ich finansowania - w szczególności w odniesieniu do gmin [Olejniczak 2015]. Funkcjonujący od 2003 roku model, uwzględniający dochody własne w podziale na: wpływy z podatków (od nieruchomości, od środków transportowych, rolnego, leśnego, od czynności cywilnoprawnych, karty podatkowej oraz od spadków i darowizn), wpływy z opłat, dochody z majątku komunalnego (z zarządzania majątkiem trwałym i zarządzania majtkiem obrotowym) oraz pozostałe dochody gmin [Kotlińska 2009], powoduje, iż system finansowania gmin sprawia wrażenie dobrze ukształtowanego i kompletnego. Jednak system ten podlega krytyce ze względu na ustanowiony katalog źródeł, możliwości wykonywania władztwa podatkowego, jak również administrowania tymi źródłami [Ofiarski 2012]. Krytyka ta dotyczy w odniesieniu do dochodów własnych gmin między innymi zróżnicowanej bazy podatkowej (w odniesieniu do występujących różnic między typami gmin), braku możliwości wykonywania władztwa podatkowego w odniesieniu do trzech analizowanych podatków (jako braku możliwości realizacji w tym zakresie długookresowej polityki podatkowej), jak również wydłużenie obiegu strumieni pieniężnych związanych z administrowaniem tymi podatkami przez naczelników urzędów skarbowych [Ofiarski 2012]. Powstaje zatem uzasadnione pytanie o znaczenie trzech wymienionych podatków dla możliwości prowadzenia polityki podatkowej poszczególnych grup i jednostek samorządu gminnego.

Analiza danych zbiorczych o strukturze dochodów gmin z ostatnich lat wskazuje, iż zwiększa się znaczenie dochodów własnych gmin na tle pozostałych dochodów zarówno w całej populacji gmin (z 44,46\% w 2010 roku do 49,7\% w 2015), jak i w gminach wiejskich (z 35,87\% w 2010 roku do 42,72\% w 2015; tabele 1 i 2). Jednocześnie należy zauważyć, iż mimo dodatniej dynamiki subwencji ogólnej (poza relacją z lat 2014/2013) oraz dotacji uzyskiwanych przez gminy (z wyłączeniem 2011/2010 oraz 2012/2011) to właśnie dynamika dochodów własnych była największa między 2010 a 2015 rokiem - relacja dochodów własnych z 2015 do tychże z 2010 wynosiła $135 \%$, podczas gdy dla dotacji było to $107 \%$, a dla subwencji $112 \%$. Dochody ogółem wszystkich gmin odnotowały dynamikę na poziomie $121 \%$. Z kolei dla gmin wiejskich dynamika dochodów ogółem wynosiła $120 \%$, dochodów własnych 144\%, dotacji 107\%, a subwencji 108\%. Tak duży wzrost dochodów własnych zarówno w gminach ogółem, jak i w gminach wiejskich wskazuje na wzrost znaczenia tej grupy dochodów i powoduje, iż powstaje pytanie o udział dochodów z trzech wcześniej wspomnianych podatków w tym przyroście.

Analiza danych o łącznych wpływach z poszczególnych podatków wskazuje, iż udział dochodów ze wspomnianych trzech podatków zmniejszał się systematycznie w obu - zarówno we wszystkich gminach, jak i w gminach wiejskich. Dodatkowo należy wskazać, iż w przypadku dochodów z podatku dochodowego opłacanego $\mathrm{w}$ formie karty podatkowej oraz podatku od czynności cywilnoprawnych widoczna 
Problem wydajności przejmowanych wpływów z wybranych podatków...

Tabela 1. Struktura dochodów gmin ogółem w latach 2010-2015 (w \%)

\begin{tabular}{|l|r|r|r|r|r|r|}
\hline \multicolumn{1}{|c|}{ Dochody/rok } & 2010 & 2011 & 2012 & 2013 & 2014 & 2015 \\
\hline $\begin{array}{l}\text { Razem dochody własne, } \\
\text { w tym: }\end{array}$ & 44,62 & 45,48 & 46,58 & 48,16 & 49,33 & 49,70 \\
\hline $\begin{array}{l}\text { udział w podatku dochodowym od osób } \\
\text { prawnych }\end{array}$ & 0,85 & 1,00 & 1,01 & 0,93 & 0,83 & 0,86 \\
\hline $\begin{array}{l}\text { udział w podatku dochodowym od osób } \\
\text { fizycznych }\end{array}$ & 13,94 & 14,95 & 15,40 & 16,02 & 16,54 & 17,44 \\
\hline podatek rolny & 1,35 & 1,38 & 1,93 & 2,04 & 1,92 & 1,79 \\
\hline podatek od nieruchomości & 12,53 & 12,88 & 13,53 & 14,13 & 13,99 & 13,95 \\
\hline podatek leśny & 0,23 & 0,25 & 0,29 & 0,28 & 0,25 & 0,26 \\
\hline podatek od środków transportowych & 0,78 & 0,79 & 0,80 & 0,80 & 0,79 & 0,79 \\
\hline podatek w formie karty podatkowej & 0,06 & 0,06 & 0,06 & 0,05 & 0,05 & 0,04 \\
\hline podatek od spadków i darowizn & 0,17 & 0,16 & 0,16 & 0,14 & 0,13 & 0,12 \\
\hline podatek od czynności cywilnoprawnych & 1,09 & 1,00 & 0,88 & 0,89 & 0,97 & 0,88 \\
\hline wpływy z opłaty skarbowej & 0,31 & 0,29 & 0,26 & 0,25 & 0,24 & 0,18 \\
\hline wpływy z opłaty eksploatacyjnej & 0,32 & 0,37 & 0,27 & 0,34 & 0,35 & 0,33 \\
\hline wpływy z opłaty targowej & 0,20 & 0,20 & 0,18 & 0,17 & 0,17 & 0,16 \\
\hline dochody z majątku & 3,63 & 3,43 & 3,49 & 3,46 & 3,31 & 3,03 \\
\hline pozostałe dochody & 9,16 & 8,73 & 8,33 & 8,65 & 9,80 & 9,88 \\
\hline Dotacje ogółem & 24,02 & 23,83 & 21,98 & 20,87 & 21,57 & 21,30 \\
\hline $\begin{array}{l}\text { Subwencja ogólna, } \\
\text { w tym: }\end{array}$ & 31,36 & 30,68 & 31,44 & 30,97 & 29,09 & 29,00 \\
\hline część wyrównawcza & 8,26 & 7,71 & 7,75 & 7,82 & 7,03 & 6,89 \\
\hline część oświatowa & 22,45 & 22,36 & 23,09 & 22,63 & 21,60 & 21,66 \\
\hline część rekompensująca & 0,01 & 0,01 & 0,01 & 0,01 & 0,01 & 0,01 \\
\hline część równoważąca & 0,46 & 0,44 & 0,45 & 0,41 & 0,39 & 0,38 \\
\hline
\end{tabular}

Źródło: opracowanie własne.

Tabela 2. Struktura dochodów gmin wiejskich w latach 2010-2015 (w \%)

\begin{tabular}{|l|c|c|c|c|c|c|}
\hline \multicolumn{1}{|c|}{ Dochody/rok } & 2010 & 2011 & 2012 & 2013 & 2014 & 2015 \\
\hline \multicolumn{1}{|c|}{1} & 2 & 3 & 4 & 5 & 6 & 7 \\
\hline $\begin{array}{l}\text { Razem dochody własne, } \\
\text { w tym: }\end{array}$ & 35,87 & 37,14 & 38,52 & 40,34 & 41,95 & 42,72 \\
\hline $\begin{array}{l}\text { udział w podatku dochodowym od osób } \\
\text { prawnych }\end{array}$ & 0,53 & 0,55 & 0,48 & 0,45 & 0,45 & 0,48 \\
\hline $\begin{array}{l}\text { udział w podatku dochodowym od osób } \\
\text { fizycznych }\end{array}$ & 10,34 & 11,35 & 11,90 & 12,63 & 13,22 & 14,08 \\
\hline podatek rolny & 1,99 & 2,04 & 2,82 & 2,95 & 2,80 & 2,60 \\
\hline
\end{tabular}


Tabela 2, cd.

\begin{tabular}{|l|c|c|c|c|c|c|}
\hline \multicolumn{1}{|c|}{1} & 2 & 3 & 4 & 5 & 6 & 7 \\
\hline podatek od nieruchomości & 9,92 & 10,19 & 10,74 & 11,43 & 11,57 & 11,49 \\
\hline podatek leśny & 0,33 & 0,36 & 0,41 & 0,41 & 0,35 & 0,37 \\
\hline podatek od środków transportowych & 0,72 & 0,75 & 0,78 & 0,79 & 0,80 & 0,81 \\
\hline podatek w formie karty podatkowej & 0,04 & 0,04 & 0,04 & 0,03 & 0,03 & 0,03 \\
\hline podatek od spadków i darowizn & 0,12 & 0,12 & 0,12 & 0,11 & 0,10 & 0,09 \\
\hline podatek od czynności cywilnoprawnych & 0,82 & 0,82 & 0,70 & 0,74 & 0,72 & 0,75 \\
\hline wpływy z opłaty skarbowej & 0,11 & 0,10 & 0,09 & 0,09 & 0,08 & 0,08 \\
\hline wpływy z opłaty eksploatacyjnej & 0,37 & 0,46 & 0,35 & 0,46 & 0,46 & 0,45 \\
\hline wpływy z opłaty targowej & 0,06 & 0,06 & 0,05 & 0,05 & 0,05 & 0,05 \\
\hline dochody z majątku & 1,88 & 1,81 & 1,75 & 1,97 & 1,92 & 1,72 \\
\hline pozostałe dochody & 8,65 & 8,50 & 8,28 & 8,24 & 9,40 & 9,72 \\
\hline Dotacje ogółem & 25,78 & 25,49 & 23,33 & 22,16 & 23,08 & 22,85 \\
\hline Subwencja ogólna, w tym: & 38,35 & 37,37 & 38,15 & 37,50 & 34,97 & 34,43 \\
\hline część wyrównawcza & 12,44 & 11,65 & 11,83 & 11,89 & 10,57 & 10,30 \\
\hline część oświatowa & 25,19 & 25,09 & 25,74 & 25,12 & 23,99 & 23,75 \\
\hline część rekompensująca & 0,001 & 0,001 & 0,001 & 0,001 & 0,001 & 0,001 \\
\hline część równoważąca & 0,46 & 0,42 & 0,43 & 0,38 & 0,33 & 0,32 \\
\hline
\end{tabular}

Źródło: opracowanie własne.

jest tendencja do spadku nominalnych dochodów z tego tytułu uzyskiwanych w obu wspomnianych grupach gmin. Należy podkreślić, iż w przypadku gmin wiejskich dynamika spadku była nieznacznie silniejsza niż w przypadku ogółu gmin (zazwyczaj o około 1 p.p. poza silnym wzrostem w 2015 roku). Jest to zatem zjawisko odwrotne do kierunku zmian łącznych dochodów własnych. O skali zjawiska świadczy fakt, iż dynamika zmiany dochodów z „karty podatkowej” w gminach między 2010 a 2015 wynosiła $85 \%$ - podobnie jak w przypadku podatku od spadków i darowizn (dla gmin wiejskich było to odpowiednio $83 \%$ i 93\%), a dynamika wpływów z podatku od czynności cywilnoprawnych wynosiła 97\% (w gminach wiejskich $110 \%$, lecz do 2014 wynosiła jedynie 98\%).

Dane zbiorcze o sytuacji ogółu gmin, jak również o wpływach z badanych podatków w gminach wiejskich jednoznacznie wskazują, iż ich znaczenie w strukturze dochodów jest marginalne i dla ogółu gmin wynosi około 1\% dochodów, a dla gmin wiejskich $0,9 \%$ dochodów.

\section{Zróżnicowanie dochodów gmin wiejskich z podatków administrowanych przez naczelników urzędów skarbowych}

We wstępnym etapie badania porównano udział poszczególnych badanych źródeł dochodów w kolejnych latach w dochodach ogółem. Przeprowadzona analiza wy- 
kazała, iż w gminach wiejskich w latach 2013-2015 nie następowały istotne zmiany (tak jak można było wnioskować z danych zbiorczych) w udziale tychże źródeł w dochodach ogółem poszczególnych gmin. Na tej podstawie przyjęto za uzasadnione z punktu widzenia zachowania przejrzystości artykułu oraz ograniczenia jego objętości zaprezentowanie wyników badań dla 2015 roku jako ostatniego z badanych okresów.

Pierwszym z analizowanych źródeł dochodów gmin jest podatek od działalności gospodarczej osób fizycznych opłacany w formie karty podatkowej. Jak można zauważyć, udział dochodów z tego podatku dla gmin wiejskich odnotowuje najniższe wartości wszystkich miar (minimum, q1, mediana, q3 oraz maksimum) względem pozostałych typów gmin, co wskazuje niewątpliwie na jego mniejsze znaczenie w tym typie gmin. Jak można również zauważyć, rozstęp między 1 a 3 kwartylem jest najmniejszy $(0,32)$, co oznacza duże podobieństwo poziomu udziału tego podatku w dochodach połowy gmin. Jednocześnie widoczne jest zróżnicowanie terytorialne rozkładu udziału tego podatku w dochodach. Analiza rozkładu przestrzennego badanej cechy zaprezentowanej na rysunku 1 wskazuje, iż gminy Polski północnej i zachodniej odnotowywały w 2015 roku niższy udział wpływów z tego podatku, podczas gdy gminy położone w pobliżu dużych miast oraz $\mathrm{w}$ regionach atrakcyjnych turystycznie (wybrzeże Bałtyku, Tatry) odnotowywały najwyższy udział wpływów $\mathrm{z}$ tego podatku w dochodach.

Tabela 3. Udziały dochodów z karty podatkowej w dochodach ogółem gmin w 2015 roku (w \%)

\begin{tabular}{|l|c|c|c|c|}
\hline Wartość/typ gminy & Łącznie & Gminy miejskie & Gminy wiejskie & Gminy miejsko-wiejskie \\
\hline Minimum & $-0,039$ & 0,000 & $-0,039$ & $-0,007$ \\
\hline Kwartyl 1 & 0,007 & 0,034 & 0,004 & 0,012 \\
\hline Mediana & 0,021 & 0,058 & 0,016 & 0,026 \\
\hline Kwartyl 3 & 0,048 & 0,093 & 0,036 & 0,053 \\
\hline Maksimum & 0,618 & 0,524 & 0,386 & 0,618 \\
\hline
\end{tabular}

Źródło: opracowanie własne.

Analiza dochodów per capita z podatku od działalności gospodarczej osób fizycznych opłacanego w formie karty podatkowej wskazuje, iż w gminach wiejskich dochody z tego podatku nie przekraczają zasadniczo 1,53 zł na mieszkańca - dla $75 \%$ zbiorowości (tabela 4). Oznacza to, iż na tle pozostałych gmin są one najniższe (choć rozstęp między 1 a 3 kwartylem jest nieznacznie wyższy niż w gminach miejsko-wiejskich), a analiza przestrzenna różnic $w$ ich poziomie nie wskazuje na istotne zróżnicowanie pod tym względem (pomijając ich wyższy poziom w niektórych gminach nadmorskich). Sytuacja taka może być spowodowana występowaniem pewnej stałej zależności, jeżeli chodzi o rodzaj, skalę i zakres możliwej i realizowanej działalności gospodarczej z wykorzystaniem tej formy opodatkowania na terenach gmin wiejskich. 


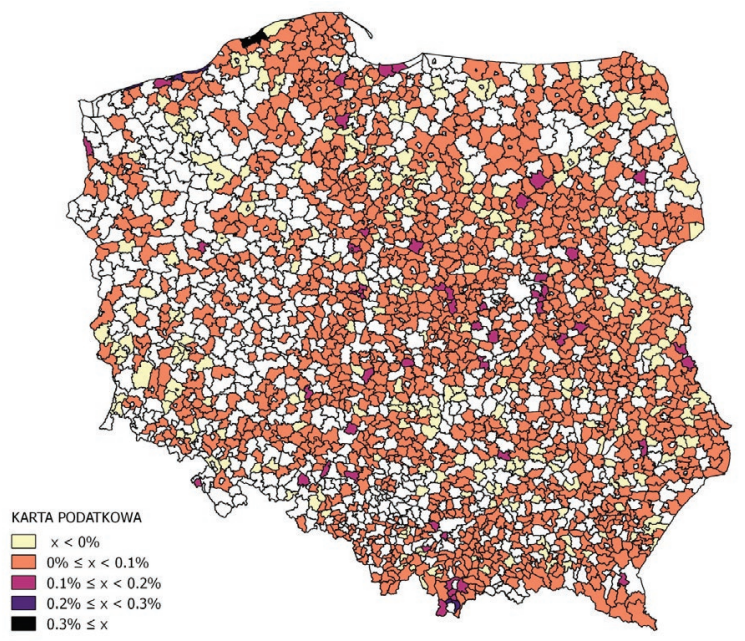

Rys. 1. Udział dochodów z karty podatkowej w dochodach w 2015 roku (gminy wiejskie) (w \%) Źródło: opracowanie własne.
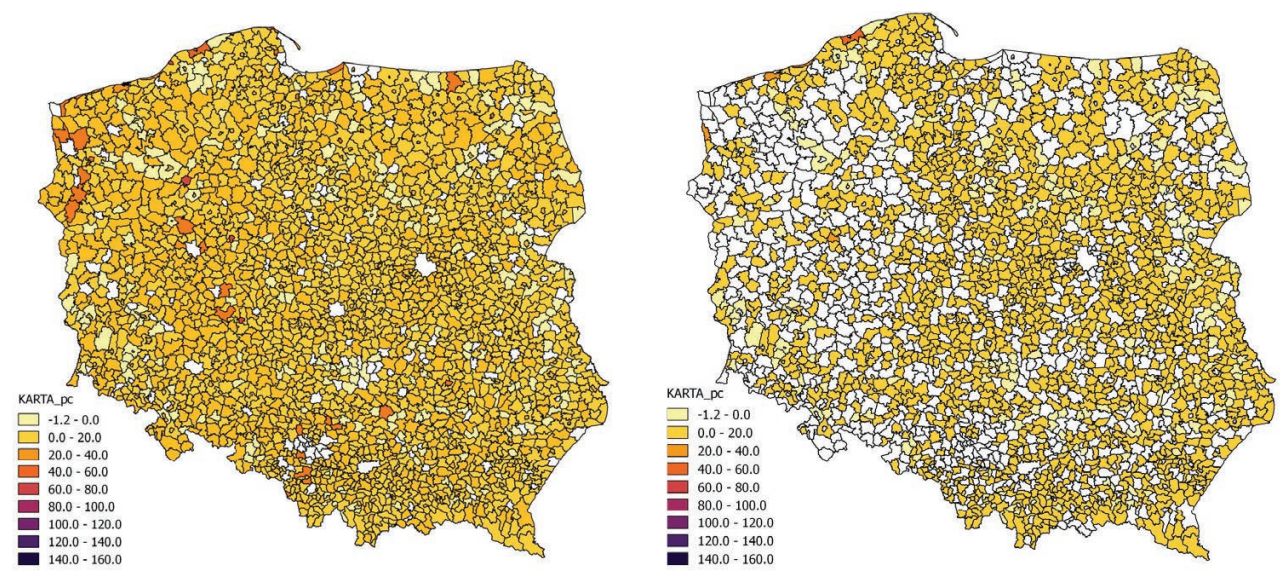

Rys. 2. Dochody per capita z karty podatkowej w 2015 roku (wszystkie gminy z wyłączeniem miast na prawach powiatu oraz gminy wiejskie) (w zł)

Źródło: opracowanie własne.

Drugim z analizowanych źródeł dochodów jest podatek od spadków i darowizn. Specyfika tego podatku wynika głównie z przedmiotu opodatkowania. Jak można domniemywać, na jego wielkość wpływać będą w największym stopniu: po pierwsze zamożność społeczeństwa, po drugie liczba ludności, po trzecie charakterystyka demograficzna ludności poszczególnych gmin. Należy podkreślić, iż znaczenie tego 
Tabela 4. Dochody z karty podatkowej per capita w gminach w 2015 roku (zł)

\begin{tabular}{|l|c|c|c|c|}
\hline \multicolumn{1}{|c|}{ Wartości } & Łącznie & Gminy miejskie & Gminy wiejskie & Gminy miejsko-wiejskie \\
\hline Minimum & $-1,25$ & 0,00 & $-1,25$ & $-0,66$ \\
\hline Kwartyl 1 & 0,28 & 1,52 & 0,14 & 0,53 \\
\hline Mediana & 0,89 & 2,83 & 0,64 & 1,25 \\
\hline Kwartyl 3 & 2,17 & 6,74 & 1,53 & 2,84 \\
\hline Maksimum & 59,68 & 59,68 & 43,83 & 33,83 \\
\hline
\end{tabular}

Źródło: opracowanie własne.

Tabela 5. Udział dochodów z podatku od spadków i darowizn w dochodach ogółem w gminach w 2015 roku (w \%)

\begin{tabular}{|l|c|c|c|c|}
\hline \multicolumn{1}{|c|}{ Wartości } & Łącznie & Gminy miejskie & Gminy wiejskie & Gminy miejsko-wiejskie \\
\hline Minimum & $-0,217$ & 0,007 & $-0,217$ & 0,002 \\
\hline Kwartyl 1 & 0,038 & 0,090 & 0,032 & 0,044 \\
\hline Mediana & 0,072 & 0,141 & 0,061 & 0,077 \\
\hline Kwartyl 3 & 0,128 & 0,199 & 0,111 & 0,127 \\
\hline Maksimum & 1,803 & 1,288 & 1,803 & 0,993 \\
\hline
\end{tabular}

Źródło: opracowanie własne.

podatku dla budżetów poszczególnych gmin jest zróżnicowane w poszczególnych latach ze względu na nieregularność występowania czynności opodatkowanych. W analizowanym 2015 roku widoczne jest podobieństwo rozkładu dochodów do lat poprzednich - gminy wiejskie charakteryzują się niższymi wartościami q1, mediany oraz q3 od pozostałych gmin. Jednocześnie w 2015 roku wartość udziału w dochodach maksymalna była wyższa niż w latach poprzednich. Na rysunku 3 widoczny jest rozkład terytorialny wspomnianych udziałów, który wskazuje, iż dla pojedynczych gmin występują wartości skrajne, a większość gmin wiejskich odnotowuje udział wpływów z tego podatku na poziomie nie większym niż 0,05\% dochodów.

Analizując poziom dochodów per capita, należy wskazać, iż zarówno w gminach wiejskich, jak i pozostałych dochody te w przeliczeniu na mieszkańca są relatywnie niskie i nie przekraczają 20 złotych na osobę (rys. 4). Tak więc można uznać, iż badając różnice w wydajności tego podatku w przeliczeniu na mieszkańca, uzasadnione jest stwierdzenie o jego zbliżonej wydajności w większości gmin (niezależnie od ich typu).

Dochody uzyskiwane przez gminy z podatku od czynności cywilnoprawnych, jak już wspomniano, nie mają istotnego znaczenia w dochodach ogółem. Udział tych dochodów w przypadku gmin wiejskich charakteryzuje się najmniejszym rozstępem 


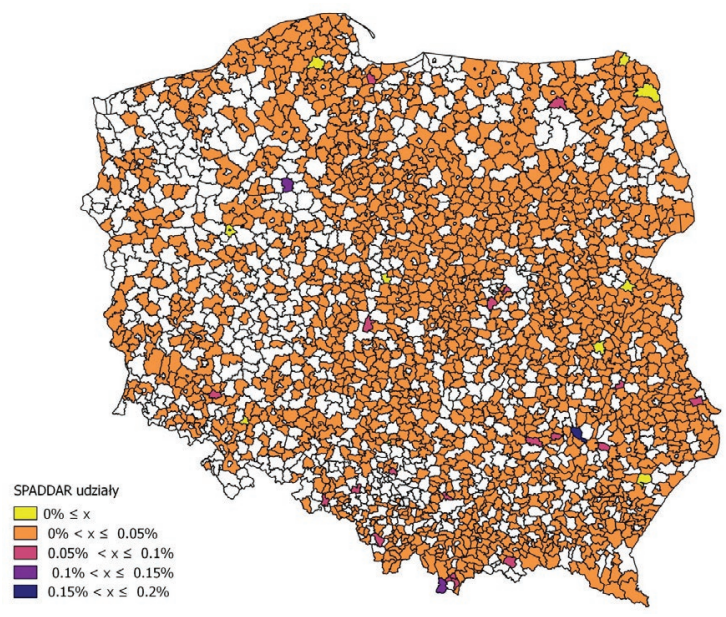

Rys. 3. Udział dochodów z podatku od spadków i darowizn w budżetach gmin wiejskich w Polsce w 2015 roku (w \%)

Źródło: opracowanie własne.

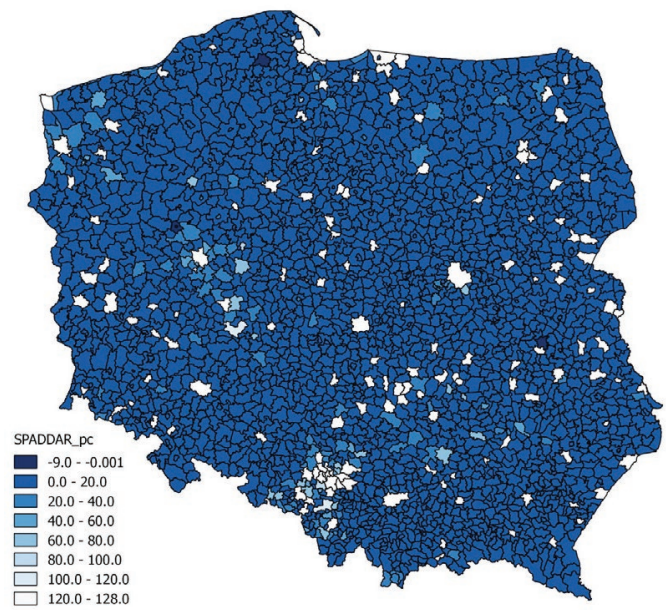

Rys. 4. Dochody per capita $\mathrm{z}$ podatku od spadków i darowizn w budżetach gmin z wyłączeniem miast na prawach powiatu w Polsce w 2015 roku (w zł)

Źródło: opracowanie własne.

międzykwartylowym $(0,79$ p.p.) oraz medianą na tle pozostałych gmin, jednak to w gminach wiejskich występują najwyższe i najniższe wartości tego udziału (tab. 6). Analizując kwoty przypadające na mieszkańca, należy zauważyć, iż uzyskiwane dochody przez gminy wiejskie wskazują w ich przypadku na bardzo niską wydajność 
Tabela 6. Udział dochodów z podatku od czynności cywilnoprawnych, płaconego przez osoby fizyczne, w dochodach ogółem budżetów gmin w 2015 roku (w \%)

\begin{tabular}{|l|c|c|c|c|}
\hline \multicolumn{1}{|c|}{ Wartości } & Lącznie & Gminy miejskie & Gminy wiejskie & Gminy miejsko-wiejskie \\
\hline Minimum & $-0,217$ & 0,007 & $-0,217$ & 0,002 \\
\hline Kwartyl 1 & 0,038 & 0,090 & 0,032 & 0,044 \\
\hline Mediana & 0,072 & 0,141 & 0,061 & 0,077 \\
\hline Kwartyl 3 & 0,128 & 0,199 & 0,111 & 0,127 \\
\hline Maksimum & 1,803 & 1,288 & 1,803 & 0,993 \\
\hline
\end{tabular}

Źródło: opracowanie własne.

tego podatku - nawet w porównaniu z gminami miejsko-wiejskimi, często charakteryzującymi się zbliżonymi wielkościami uzyskiwanych dochodów do gmin wiejskich (tab. 7).

Tabela 7. Dochody per capita z podatku od czynności cywilnoprawnych, płaconego przez osoby fizyczne, w budżetach gmin w dochodach ogółem budżetów gmin w 2015 roku (w zł)

\begin{tabular}{|l|c|c|c|c|}
\hline \multicolumn{1}{|c|}{ Wartości } & Łącznie & Gminy miejskie & Gminy wiejskie & Gminy miejsko-wiejskie \\
\hline Minimum & $-43,49$ & 6,49 & $-3,57$ & $-43,49$ \\
\hline Kwartyl 1 & 13,12 & 24,19 & 11,35 & 17,36 \\
\hline Mediana & 20,47 & 35,79 & 16,69 & 25,10 \\
\hline Kwartyl 3 & 37,74 & 119,99 & 30,01 & 48,88 \\
\hline Maksimum & 3293,51 & 1073,42 & 3293,51 & 604,05 \\
\hline
\end{tabular}

Źródło: opracowanie własne.

Analiza rozkładu terytorialnego, zarówno ze względu na poziom udziału (rys. 5), jak i na wartość w przeliczeniu na mieszkańca (rys. 6), wskazuje natomiast na silne powiązanie niektórych gmin wiejskich (jak również miejsko-wiejskich) z sąsiadującymi z nimi miastami na prawach powiatu, generujące istotnie wyższe od przeciętnych wskaźniki. Koncentracja ta szczególnie widoczna jest w przypadku gmin sąsiadujących z Poznaniem, Szczecinem, Gdańskiem-Gdynią-Sopotem, Warszawą, aglomeracją górnośląską. Niższe wartości per capita w przypadku części gmin sąsiadujących np. z Wrocławiem, Krakowem czy Łodzią spowodowane mogą być większą gęstością zaludnienia tych gmin.

W przypadku powyższego podatku płaconego przez osoby prawne udział tego podatku, jak i kwoty w przeliczeniu na mieszkańca wydają się w większości gmin symboliczne. Dla gmin wiejskich mediana udziału dochodów z tytułu tego podatku w dochodach ogółem to ledwie $0,003 \%$, natomiast wartość maksymalna uzyskana w 2015 roku to aż 13,64\%. Co ciekawe w takim ujęciu ponownie gminy wiejskie wykazują najmniejsze zróżnicowanie, bowiem w ich przypadku rozstęp międzykwartylowy wynosił jedynie 0,015 p.p., przy czym widoczna jest większa koncen- 


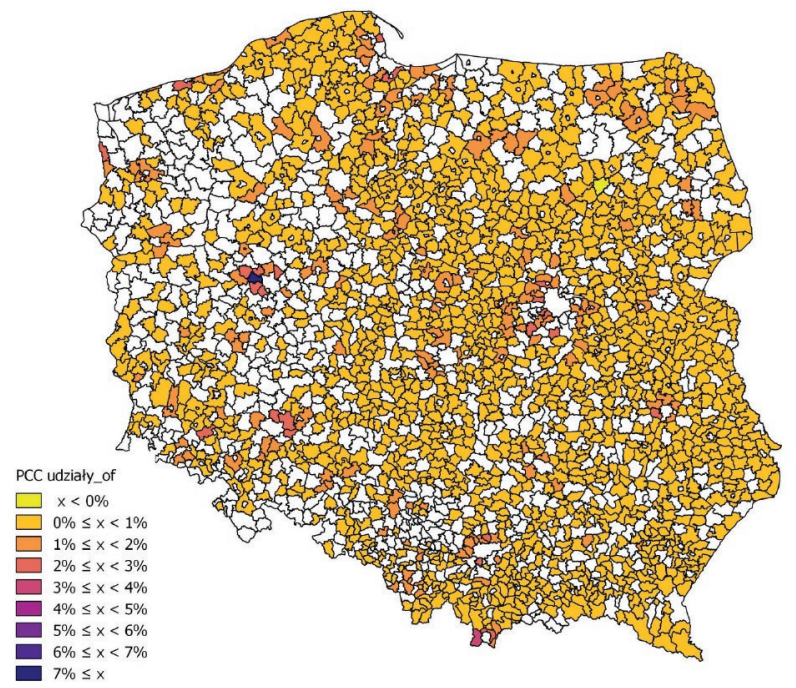

Rys. 5. Udział dochodów z podatku od czynności cywilnoprawnych, płaconego przez osoby fizyczne, w dochodach ogółem budżetów gmin z wyłączeniem miast na prawach powiatu w Polsce w 2015 roku (w \%)

Źródło: opracowanie własne.

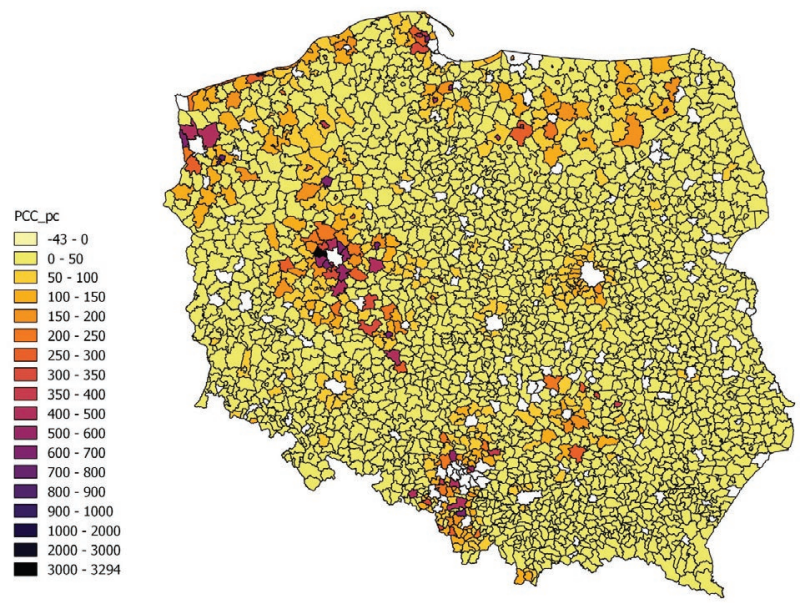

Rys. 6. Dochody per capita z podatku od czynności cywilnoprawnych, płaconego przez osoby fizyczne, w budżetach gmin z wyłączeniem miast na prawach powiatu w Polsce w 2015 roku (w zł) Źródło: opracowanie własne.

tracja gmin między minimum a medianą niż między medianą a maksimum. Należy zauważyć, iż w przypadku ogółu gmin powtarza się sytuacja, w której największe zróżnicowanie dochodów ma miejsce w gminach miejskich - przy czym wartości 
skrajne nie stanowią tu istotnego odstępstwa od mediany czy też wartości 1 i 3 kwartylu (tab. 8).

Tabela 8. Udział dochodów z podatku od czynności cywilnoprawnych, płaconego przez osoby prawne, w dochodach ogółem budżetów gmin w 2015 roku (w \%)

\begin{tabular}{|l|c|c|c|c|}
\hline \multicolumn{1}{|c|}{ Wartości } & Łącznie & Gminy miejskie & Gminy wiejskie & Gminy miejsko-wiejskie \\
\hline Minimum & $-3,146$ & $-3,146$ & $-1,640$ & $-0,730$ \\
\hline Kwartyl 1 & 0,001 & 0,005 & 0,000 & 0,001 \\
\hline Mediana & 0,005 & 0,020 & 0,003 & 0,007 \\
\hline Kwartyl 3 & 0,023 & 0,064 & 0,015 & 0,028 \\
\hline Maksimum & 13,644 & 0,664 & 13,644 & 2,610 \\
\hline
\end{tabular}

Źródło: opracowanie własne.

Analiza rozkładu terytorialnego badanego podatku nie wskazuje na występowanie istotnych powiązań między lokalizacją danej gminy w konkretnym województwie czy też sąsiedztwie a poziomem udziału (rys. 7) czy wartością tego podatku per capita (rys. 8). Także dochody z tego podatku per capita - jak można było się spodziewać - nie są znacząco zróżnicowane między województwami, a obserwowane wyższe wartości wynikają głównie z lokalizacji w poszczególnych gminach pojedynczych dużych podmiotów gospodarczych opłacających ten podatek. Z drugiej strony to $w$ gminach wiejskich odnotowuje się znacząco mniejsze wartości per capita zarówno pierwszego, mediany, jak również trzeciego kwartyla.

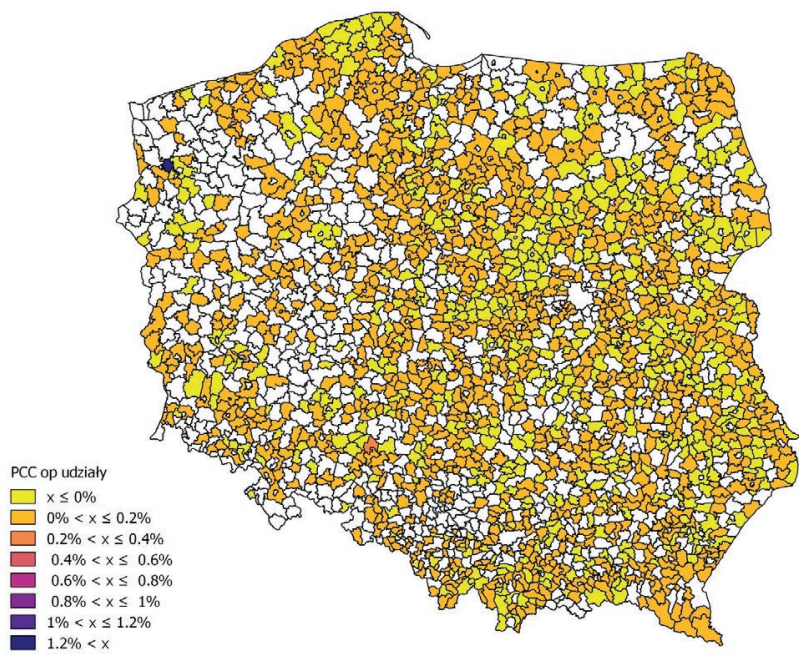

Rys. 7. Udział dochodów z podatku od czynności cywilnoprawnych, płaconego przez osoby prawne, w dochodach budżetów gmin z wyłączeniem miast na prawach powiatu w Polsce w 2015 roku (w \%)

Źródło: opracowanie własne. 


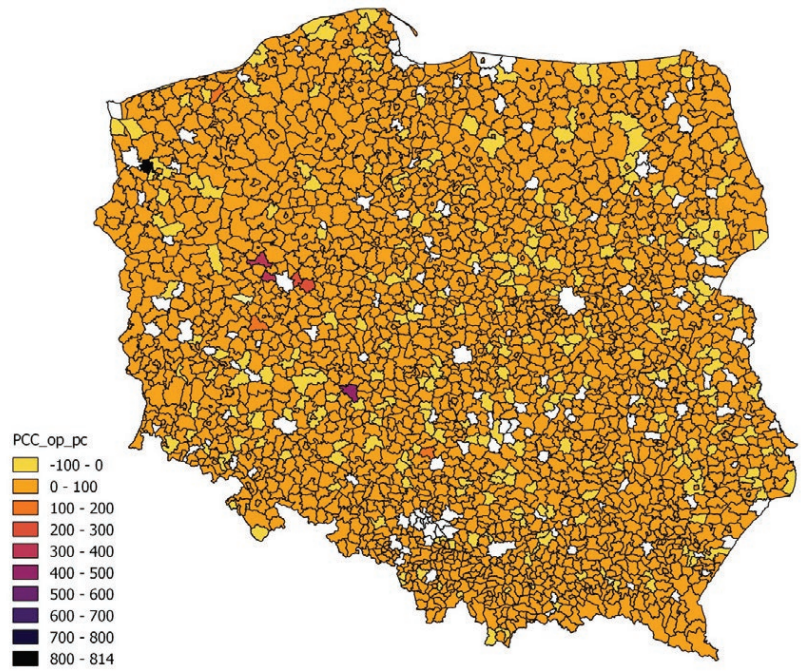

Rys. 8. Dochody per capita z podatku od czynności cywilnoprawnych, płaconego przez osoby prawne, w budżetach gmin z wyłączeniem miast na prawach powiatu w Polsce w 2015 roku (w zł)

Źródło: opracowanie własne.

Tabela 9. Dochody per capita z podatku od czynności cywilnoprawnych, płaconego przez osoby prawne, w budżetach gmin w dochodach ogółem budżetów gmin w 2015 roku (w zł)

\begin{tabular}{|l|c|c|c|c|}
\hline \multicolumn{1}{|c|}{ Wartości } & Łącznie & Gminy miejskie & Gminy wiejskie & Gminy miejsko-wiejskie \\
\hline Minimum & $-119,25$ & $-108,06$ & $-48,06$ & $-119,25$ \\
\hline Kwartyl 1 & 0,03 & 0,22 & 0,02 & 0,06 \\
\hline Mediana & 0,19 & 1,10 & 0,12 & 0,35 \\
\hline Kwartyl 3 & 1,03 & 4,34 & 0,69 & 1,50 \\
\hline Maksimum & 814,45 & 96,09 & 814,45 & 483,42 \\
\hline
\end{tabular}

Źródło: opracowanie własne.

Dochody z podatku od czynności cywilnoprawnych w przeliczeniu na mieszkańca kształtują się w gminach wiejskich na bardzo niskim poziomie. W 3/4 gmin wiejskich nie przekraczały one 70 gr w 2015 roku, podczas gdy w gminach miejskich sięgały one nawet niemal 4,50 zł.

\section{Zakończenie}

Podjęte badania wykazały, iż od 2010 roku - mimo wzrastającego udziału dochodów własnych w dochodach ogółem w przypadku zarówno ogółu gmin, jak i gmin wiejskich - obserwowalny jest spadek uzyskiwanych przez wszystkie gminy dochodów nominalnych z analizowanych podatków, co skutkuje spadkiem ich udzia- 
łów w dochodach ogółem. W przypadku gmin wiejskich występowała podobna tendencja - poza PCC, w przypadku którego gminy wiejskie odnotowywały coroczny wzrost wartości nominalnej uzyskiwanych dochodów. Badanie zróżnicowania dochodów gmin wiejskich w poszczególnych podatkach wskazuje, na tle pozostałych gmin, na mniejsze zróżnicowanie udziału dochodów ze wspomnianych podatków $\mathrm{w}$ dochodach własnych oraz niższy poziom dochodów per capita $\mathrm{w}$ przeliczeniu na mieszkańca - przy czym widoczne są nieliczne istotne odchylenia od wartości mediany (szczególnie w przypadku PCC). Przeanalizowany rozkład terytorialny, zarówno udziałów w dochodach, jak i wskaźników badanych dochodów na mieszkańca, przynosi konkluzję, iż koncentracja wyższych wartości uzyskanych wskaźników widoczna jest głównie wokół silnych ośrodków miejskich i w województwach uważanych za silne gospodarczo (mazowieckie, śląskie, wielkopolskie, dolnośląskie czy pomorskie). Podsumowując należy wskazać, iż badane źródła dochodów odgrywają w większości gmin wiejskich marginalną rolę ze względu na słabą bazę podatkową w większości badanych gmin wiejskich.

\section{Literatura}

Kosek-Wojnar M., Surówka K., 2002, Finanse samorządu terytorialnego, Wydawnictwo Akademii Ekonomicznej w Krakowie, Kraków.

Kotlińska J., 2009, Dochody własne jednostek samorzadu terytorialnego, Ruch Prawniczy, Ekonomiczny i Socjologiczny, nr 71, z. 3, s. 143-161.

Ofiarski Z., 2012, Władztwo daninowe oraz administrowanie podatkowymi źródłami dochodów własnych gmin - czy podziat kompetencji jest jeszcze potrzebny? Zeszyty Naukowe Instytutu Administracji AJD w Częstochowie, nr 1, s. 137-151.

Olejniczak J., 2015, Should We Differentiate Systems of Own Revenues in Rural and Urban Local Self-Governments' Budgets? Example from Lower Silesian Voivodeship, Smutka L., Rezbova H., (ed.), Proceedings of the 24th Agrarian Perspectives XXIV, Global Agribusiness and Rural Economy International Scientific Conference, Czech University of Life Science Prague, Faculty of Economics and Management, s. 324-331.

Sprawozdania z wykonania budżetów gmin, http://www.mf.gov.pl/ministerstwo-finansow /dzialalnosc/ finanse-publiczne/budzety-jednostek-samorzadu-terytorialnego/sprawozdania-budzetowe (stan na dzień 14.05.2017).

Ustawa o dochodach jednostek samorządu terytorialnego z dnia 13 listopada 2003 roku, Dz.U. z 2003, nr 203, poz. 1966 z późn. zm. 